International Journal of Social Science and Economic Research

ISSN: 2455-8834

Volume:06, Issue:06 "June 2021"

\title{
USING INCOME TAX REGIME TO EFFICIENTLY UTILIZE RESOURCES
}

\author{
Ayush Gajwani \\ completed Integrated MSc from IIT Kharagpur, lives in Durg, Chhattisgarh, India \\ DOI: 10.46609/IJSSER.2021.v06i06.011 URL: https://doi.org/10.46609/IJSSER.2021.v06i06.011
}

\begin{abstract}
This Paper discusses about how income tax regime can be utilized to increase velocity of money in the economy. I am imagining a system where in there is an incentive for individuals to spend so that money flows smoothly throughout the system and in the process we can provide ample opportunities to the people who are willing to work hard.
\end{abstract}

Keywords : Income tax exemptions, velocity of money, aggregate demand

\section{Introduction}

God had made us in a way that we need oxygen, food and water to survive. Fortunately, God had been kind to us to provide all these in abundance so that we don't need to struggle very hard to get it. We have introduced money and it is also a necessity for people to survive, but unlike God, we have been very unkind to humanity to leave it only to "the invisible hand" to decide if everyone can get it. In fact, money by its nature has turned out to be in a way that minority of population gets majority of money and majority of population gets only minority. This majority population goes through a terrible mental pressure and suffering. Hence, we need to continuously evolve "the invisible hand" to reduce the suffering of this majority population.

\section{Problem}

I would be very naïve to say that money is the problem. I totally agree with the thought that to demand from the society you have to supply to the society and money system is the best solution till now to make sure that it is happening. The problem arises when the people who are willing to work hard to contribute to the supply side don't get opportunity and hence are forced to demand less. In this process loser is not just the person not getting the opportunity but also the society because society is also not able to utilize that person to create something meaningful. This lack of opportunity is happening not just because we don't need these many people to contribute to the supply side, but also because majority of people want to save extremely high proportion of their hard-earned money for future by compromising with their present-day needs. Let me 


\section{International Journal of Social Science and Economic Research}

ISSN: $2455-8834$

Volume:06, Issue:06 "June 2021"

explain this point with an extremely simple example - There are 2 person $\mathrm{Mr}$. A and Mr. B who need each other's service today and both are charging $\$ 100$. Problem happens when both $\mathrm{Mr}$. A and Mr. B decide to save their hard-earned money today for future by compromising with their today's problem when both of them could use each other's service to solve today's problem and at the end they will both still have their\$ 100. It's like a prisoner's dilemma where people are making suboptimal choices.

\section{Solution}

Income tax system! We are living in an era of democracy and giving as much liberty to people as possible is at our core, hence we cannot snatch away the liberty of people to decide whether they should spend their hard-earned money for solving their problems or save their money for future and compromise with their today's problems. But we can incentivize them to go ahead with the first option. The best way I could think of to incentivize them is to use Income tax system.

There is already a group of renowned economists around the world who propose to abolish income tax as rich peoplefind loopholes and ways to hide their wealth and most hurt is the majority middle class. I am arguing to keep income tax and use it as a tool to increase the velocity of money which is the rate at which money is exchanging hands in the economy.

I am proposing to introduce exemptions in income tax that are function of (or directly proportional to)expenses. The exemption can be full/part/none based on where the individual is spending. We can have higher (or even full) exemption for essential goods \& services and nonessential (pure) services and lower (or even none) exemption on luxury and harmful items and non-renewable resources. For goods there can be part exemptions as there is an intrinsic value of the good that can't be exempted.

Keynesian economists also accept this fact that aggregate demand strongly influences economic output and propose fiscal policy actions by the government. They propose that when aggregate demand is low, government should intervene and pump liquidity into the system. But we have seen that in general private sectors have been more efficient than public sectors due to many factors like crony capitalism, corruption, bureaucracy etc. The government pumping liquidity into the system would increase the demand and since it is comparatively inefficient than private sector, supply might not increase as much as demand which might result in inflation. The inflation in turn might further supress the demand whereas the government intervention was proposed to stabilise the demand. Hence, I am suggesting that it should be velocity of money and not liquidity that governments should focus on. High velocity of money will be much more efficient solution than high liquidity as it will efficiently increase both supply and demand. This will have multiplier effect as well. 


\section{International Journal of Social Science and Economic Research}

ISSN: $2455-8834$

Volume:06, Issue:06 "June 2021"

We have also observed in India that high tendency for savings is also because of fear of future. People need high savings for medical emergencies and quality education of their children. Hence governments should offset this fear by improving the quality of public healthcare and education to make this solution more effective.

\section{Implementation process}

It is obviously easier said than done because it will require a lot of efforts particularly because people don't keep track of their daily expenses. But they will start doing thatwhen they know that they will get exemptions based on their expenses. We can also provide them the option of choosing between a fixed exemption or availing exemption by declaring all the expenses. The fixed exemption should be neither too low, as people availing fixed exemption would generally be poor / middle class people and as a result they might end up paying higher taxes nor it should be too high that people in general are reluctant to report their transactions and as a result there is no incentive and governments have also lost some revenue. Also, we would need the seller / service provider to approve the buyer claim because otherwise there will be complete mess.

The process could be similar to that of Tax deducted at source in India. Seller would at the time of transaction would generate an invoice from a centralized system and has to put PAN number of the buyer. The centralized system then would automatically reflect the transaction and approved exemption against that PAN number. This process will also expand the income tax net as it will create an interlocking mechanism of compliance and there would be more transparency in the system.

\section{Speed Breakers}

It might be challenging to implement in countries where illiteracy is high or people are less tech savvy. Hence, I have suggested to keep an option of a fixed exemption. This will solve the problem for customers but what about sellers? I expect sellers who are not that tech savvy will also be guided by their customers on how can they approve the transaction as customers would want to avail exemptions on all their transactions. Hence in this process sellers who till now had never declared their revenues will also start putting every transaction on a centralised system.

\section{Conclusion}

We have already seen that incentives of exemptions work when we had introduced Section 80C to boost investments in India. Now I am thinking about replicating it to expenses without any upper limit (although exemptions cannot be higher than the total income)to boost demand and increase production capacity. We can't provide exemptions on all goods and services equally, hence there should be a differential system. We would want to play this card strategically. 
This method of taxing seems more logical as we would want to tax only that proportion of income which is not contributing back to society. With the motivation of saving on tax, people will spend more and there will be less "hoarding of money". Money would also start flowing like water and there will be less resistance for spending money and in the process we might create much needed opportunity to contribute. There by we will be able to better utilize many of the currently underutilized or unutilized resources. Also, this will not come at the significant cost for the exchequer as when person $\mathrm{A}$ will be spending and availing services from person $\mathrm{B}$, the exemption provided to person A will increase the taxable income of person B by same amount. Person B also then would want to spend even more to utilize exemptions and save on income tax. Also, there would be increased compliance as discussed above, so net income tax collections also won't suffer drastically or might even increase. Number of transactions would be increasing significantly; hence indirect tax collections would also increase significantly. Apart from that government could save on many welfare schemes that are provided to people who are currently not getting enough opportunities but might get in new system.

\section{References}

I have not referred to any other Journal (Print / Electronic) or book or conference paper to write this article. 